\title{
Maltose transport in Bacillus licheniformis NCIB 6346
}

\author{
Martin Tangney, Pamela Smith, Fergus G. Priest and Wilfrid J. Mitchell* \\ Department of Biological Sciences, Heriot-Watt University, Riccarton, Edinburgh EH14 4AS, UK
}

(Received 8 April 1992; revised 3 June 1992; accepted 12 June 1992)

\begin{abstract}
Bacillus licheniformis NCIB 6346 utilized glucose in preference to maltose when both sugars were present in the growth medium. Addition of glucose to a culture growing on maltose resulted in inhibition of maltose uptake and an immediate cessation of maltose metabolism. The mechanism of maltose transport was examined in whole cells and cell extracts. Phosphoenolpyruvate did not stimulate phosphorylation of maltose, indicating the absence of a phosphotransferase system. However, the presence of a maltose phosphorylase enzyme was suggested by phosphorylation of the sugar in the presence of inorganic phosphate. Maltose accumulation was strongly inhibited by proton conducting uncouplers, and was driven by an artificial transmembrane pH gradient, inside alkaline. These results imply that maltose is transported by a proton symport mechanism in this bacterium.
\end{abstract}

\section{Introduction}

Sugars are generally transported into bacterial cells via some active mechanism which uses energy to accumulate the molecules against a concentration gradient. Several mechanisms of energy coupling to sugar accumulation have been identified. A widespread mechanism involves the use of ion gradients to drive symport systems in which uptake of the sugar is accompanied by uptake of the relevant ion. A large number of bacterial transport processes operate by proton symport, in which protons serve as the coupling ions and accumulation of the substrate is driven by respiration or ATP hydrolysis via the intermediary of a transmembrane electrochemical proton gradient or protonmotive force (Booth, 1988). A characteristic of these systems is that substrate accumulation is prevented in the presence of uncouplers such as tetrachlorosalicylanilide (TCS) or carbonyl cyanide $m$-chlorophenylhydrazone (CCCP), which increase the proton conductance of the membrane and so collapse the electrochemical gradient.

Other transport systems are coupled to phosphatebond energy. The most widespread example of this type is the phosphoenolpyruvate (PEP)-dependent sugar phosphotransferase system, or PTS. This system is

* Author for correspondence. (Tel. (031) 449 5111; fax (031) 451 3009; E-mail BBSFGP@UK.AC.HW.CLUST.

\footnotetext{
Abbreviations: PEP, phosphoenolpyruvate; PTS, phosphotransferase system; CCCP, carbonyl cyanide $m$-chlorophenylhydrazone; TCS, tetrachlorosalicylanilide.
}

responsible for the transport and phosphorylation of several sugars in Escherichia coli, Bacillus subtilis, and many other obligately and facultatively anaerobic bacteria (Reizer et al., 1988; Meadow et al., 1990) and its presence is usually indicated by PEP-dependent phosphorylation of sugar in permeabilized cells or cell-free extracts. Some other sugars, such as maltose, are transported into $E$. coli via a multicomponent system including a periplasmic binding protein, using energy derived from ATP (Dean et al., 1989). Nucleic acid sequence homologies have been cited as evidence for the presence in Gram-positive bacteria of transport systems belonging to this family, despite the lack of a periplasm in these organisms. In this way, a peptide transport system has been identified in B. subtilis (Perego et al., 1991), but as yet there are no reports of ATP-dependent sugar transport systems in bacilli.

Bacillus licheniformis is a close relative of $B$. subtilis and is a major industrial organism, being used for most of the world's production of $\alpha$-amylase and alkaline protease. In these circumstances, starch is almost invariably used as the major carbon source for economic reasons and to avoid catabolite repression of enzyme synthesis. Starch is hydrolysed during the fermentation by $\alpha$-amylase to low molecular mass maltooligosaccharides, but there is little information on the mode of transport and metabolism of these digestion products. There are two possible routes for the further catabolism of these sugars. They could be hydrolysed externally by membrane-bound $\alpha$-glucosidases prior to the accumulation of glucose, as has been found in Selenomonas ruminantium (Martin \& Russell, 
1988). Alternatively, maltose and other maltooligosaccharides could be transported intact into the cell, as they are in $E$. coli (Hengge \& Boos, 1983), followed by hydrolysis in the cytoplasm. With the exception of one report identifying a PTS for glucose and fructose (Kornberg \& Miller, 1972), there is no information on transport mechanisms in $B$. licheniformis. We have now examined the uptake of maltose and show that the sugar is transported by a non-PTS system, thus indicating the latter route for maltose catabolism in this organism.

\section{Methods}

Organism and growth conditions. Bacillus licheniformis NCIB 6346 was maintained on nutrient agar slopes with subculturing every 4 weeks. The growth medium used for routine culturing was minimal salts (Thirunavukkarasu \& Priest, 1980) consisting of $\left(1^{-1}\right): \mathrm{K}_{2} \mathrm{HPO}_{4}, 14 \mathrm{~g}$; $\mathrm{KH}_{2} \mathrm{PO}_{4}, 6 \mathrm{~g} ;\left(\mathrm{NH}_{4}\right)_{2} \mathrm{SO}_{4}, 2 \mathrm{~g}$; trisodium citrate, $1 \mathrm{~g} ; \mathrm{MgSO}_{4} .7 \mathrm{H}_{2} \mathrm{O}$, $0.2 \mathrm{~g}$. The $\mathrm{pH}$ was adjusted to 6.5 and the medium sterilized by autoclaving at $121^{\circ} \mathrm{C}$ for $15 \mathrm{~min}$. Carbon sources were autoclaved separately and added to the medium to a concentration of $0.5 \%(\mathrm{w} / \mathrm{v})$.

Cultures were incubated overnight at $37^{\circ} \mathrm{C}$ in an orbital shaker (120 r.p.m.) in flasks containing a coiled spring. A portion of this culture was used to inoculate fresh medium to give an optical density at $600 \mathrm{~nm}$ of $0 \cdot 1$ to $0 \cdot 2$, and incubation was continued until the culture reached the required growth phase. For studies on whole cells and permeabilized cells, cultures were routinely harvested in midexponential phase, while extracts were prepared from cells harvested in late-exponential phase. Harvesting was by centrifugation at $6000 \mathrm{~g}$ for $15 \mathrm{~min}$ at $4{ }^{\circ} \mathrm{C}$. The pellet was washed in $100 \mathrm{~mm}$-potassium phosphate buffer, pH 6.5 , and finally resuspended in a suitable volume of buffer. Dry weight was calculated using the relationship $\mathrm{mg}$ dry wt $\mathrm{ml}^{-1}=\mathrm{OD}_{680} \times 0.33$ (Kornberg \& Miller, 1972).

Assay of sugar concentration in culture supernatants. Glucose was determined by the glucose oxidase-peroxidase method (Sigma assay kit no. 510A). Maltose was determined following hydrolysis to glucose. Samples of culture supernatant were treated with maltase for $1 \mathrm{~h}$ at $37^{\circ} \mathrm{C}$, and portions of the hydrolysed samples were then assayed for glucose. Samples containing known concentrations of maltose gave the expected results when treated in this way. When both glucose and maltose were present in the culture, the amount of glucose assayed before hydrolysis of maltose was subtracted from the value obtained after hydrolysis to allow calculation of the maltose concentration.

Measurement of sugar uptake by whole cells. A suspension containing $1 \mathrm{mg}$ cells in $100 \mathrm{~mm}$-potassium phosphate buffer, $\mathrm{pH} \mathrm{6.5,} \mathrm{was} \mathrm{allowed}$ to equilibrate at $37^{\circ} \mathrm{C}$ for $3 \mathrm{~min}$, and radiolabelled sugar $[9.5 \mathrm{~mm}$; $\left.1.05 \mathrm{Ci} \mathrm{mol}^{-1}\left(38.9 \mathrm{GBq} \mathrm{ml}^{-1}\right)\right]$ was added to give a final concentration of $0.2 \mathrm{mM}$. The total assay volume was $1.0 \mathrm{ml}$. At the times indicated, samples $(0.15 \mathrm{ml})$ were removed, filtered through glass-fibre discs (Whatman GF/F) and washed with $10 \mathrm{ml}$ of buffer. Discs were dried under a heat-lamp, and counted in scintillation cocktail $0(4 \mathrm{ml}$; BDH Scintran).

Preparation of cell extracts. Extracts were prepared by the method of Mitchell \& Booth (1984). Cells were harvested and washed as described above, resuspended in $100 \mathrm{~mm}$-potassium phosphate buffer at a ratio of $4 \mathrm{ml}$ per $\mathrm{g}$ wet $\mathrm{wt}$, and ruptured by passage through a French pressure cell at $20000 \mathrm{lbf}^{-2}$ (about $138 \mathrm{MPa}$ ). Cell debris was removed by centrifugation at $10000 \mathrm{~g}$ for $30 \mathrm{~min}$, and the supernatant recovered and stored at $-20^{\circ} \mathrm{C}$ until used. The entire procedure was carried out at $0-4{ }^{\circ} \mathrm{C}$.
Assay of sugar phosphorylation. Phosphorylation of sugars by toluenized cells and cell extracts was followed by the method of Gachelin (1969) as described by Roohi \& Mitchell (1987). The assay volume in all cases was $1.0 \mathrm{ml}$. Permeabilized cells $(1 \mathrm{mg}$ in potassium phosphate buffer) or extracts $(0.4 \mathrm{ml}$ in potassium phosphate buffer) were equilibrated at $37^{\circ} \mathrm{C}$ for $3 \mathrm{~min}$ in the presence of $5 \mathrm{mM}-\mathrm{MgCl}_{2}$ and, where appropriate, either $1 \mathrm{mM}-\mathrm{PEP}$ or $1 \mathrm{mM}$-ATP. Radiolabelled sugar $\left(9.5 \mathrm{mM} ; 1.05 \mathrm{Ci} \mathrm{mol}^{-1}\right)$ was added to $0.2 \mathrm{mM}$, and samples were taken at the times indicated for estimation of sugar phosphate. Samples $(0.15 \mathrm{ml})$ were added to $2 \mathrm{ml} 1 \%(\mathrm{w} / \mathrm{v})$ barium bromide in $80 \%(\mathrm{v} / \mathrm{v})$ ethanol. Precipitates were removed by filtration on glass-fibre discs (Whatman GF/F) and washed with $5 \mathrm{ml} 80 \%$ (v/v) ethanol, and radioactivity was determined as described above. Activity is expressed as $\mathrm{nmol} \mathrm{ml} \mathrm{m}^{-1}$ (for reaction mixtures) or $\mathrm{nmol} \mathrm{mg}^{-1}$ (for cells).

Measurement of ATP. Intracellular pools of ATP were estimated by the firefly luciferase enzyme system described by Kimmich et al. (1975) as modified by Stewart et al. (1985). Whole cell suspensions were prepared in $100 \mathrm{~mm}$-HEPES buffer, $\mathrm{pH} 6.6$, at a concentration of $2 \mathrm{mg} \mathrm{ml}^{-1}$, and were diluted twofold in assay mixtures. During experimental incubations, $1 \mathrm{ml}$ samples were removed and added to $1 \mathrm{ml}$ ice-cold $12 \%(\mathrm{v} / \mathrm{v})$ perchloric acid containing $5 \mathrm{~mm}$-phosphoric acid. After $30 \mathrm{~min}$ at $4{ }^{\circ} \mathrm{C}$, the samples were neutralized by addition of $1 \mathrm{ml} 2 \mathrm{M}-\mathrm{KOH}$ containing $0.3 \mathrm{M}$-MOPS. The samples were then frozen to aid precipitation of potassium perchlorate, thawed and centrifuged at $4{ }^{\circ} \mathrm{C}$ for $15 \mathrm{~min}$ at $5000 \mathrm{~g}$. Supernatants were removed and stored at $-20^{\circ} \mathrm{C}$ until assayed for ATP content.

The stored supernatants were thawed and recentrifuged, and decanted into new tubes. Samples $(50 \mu \mathrm{l})$ were added to $925 \mu \mathrm{l}$ of assay buffer containing $20 \mathrm{~mm}$-glycylglycine, $5 \mathrm{~mm}$-sodium arsenate and $4 \mathrm{mM}^{-\mathrm{MgSO}_{4}}$, brought to $\mathrm{pH} 8$ with $\mathrm{NaOH}$. To start the reaction, $25 \mu \mathrm{l}$ of Sigma fireffy lantern extract (FLE-50) was added, and the suspension was vortexed. After a standard $30 \mathrm{~s}$ delay, the sample was counted for three consecutive periods of $10 \mathrm{~s}$ in a LKB Wallac 1251 luminometer, and the mean of the three values used to estimate the ATP concentration. The assay was calibrated by subjecting samples of ATP at concentrations between 1 and $5 \mathrm{nM}$ to the extraction and assay procedure, and counts were found to be directly proportional to the ATP concentration.

Materials. Phosphoenolpyruvate [tri(cyclohexylammonium) salt] and maltase were purchased from Sigma, and adenosine 5 '-triphosphate (disodium salt) from Boehringer. $D-\left[U-{ }^{14} \mathrm{C}\right]$ Glucose and $\left[\mathrm{U}-{ }^{14} \mathrm{C}\right]$ maltose were obtained from Amersham. TCS was the kind gift of Professor I. R. Booth, University of Aberdeen. All other chemicals were of the highest purity available.

\section{Results}

\section{Sugar transport and utilization}

Preliminary experiments were carried out to establish the uptake patterns for glucose and maltose in $B$. licheniformis. Suspensions of washed cells which had been grown on either glucose or maltose as the sole carbon source were assayed for uptake of each of the sugars. Cells accumulated glucose irrespective of which sugar had been used for growth, although the rate of uptake was lower in maltose-grown cells. However, maltose was accumulated only by maltose-grown cells (Table 1). This indicated that glucose transport may be constitutive, 

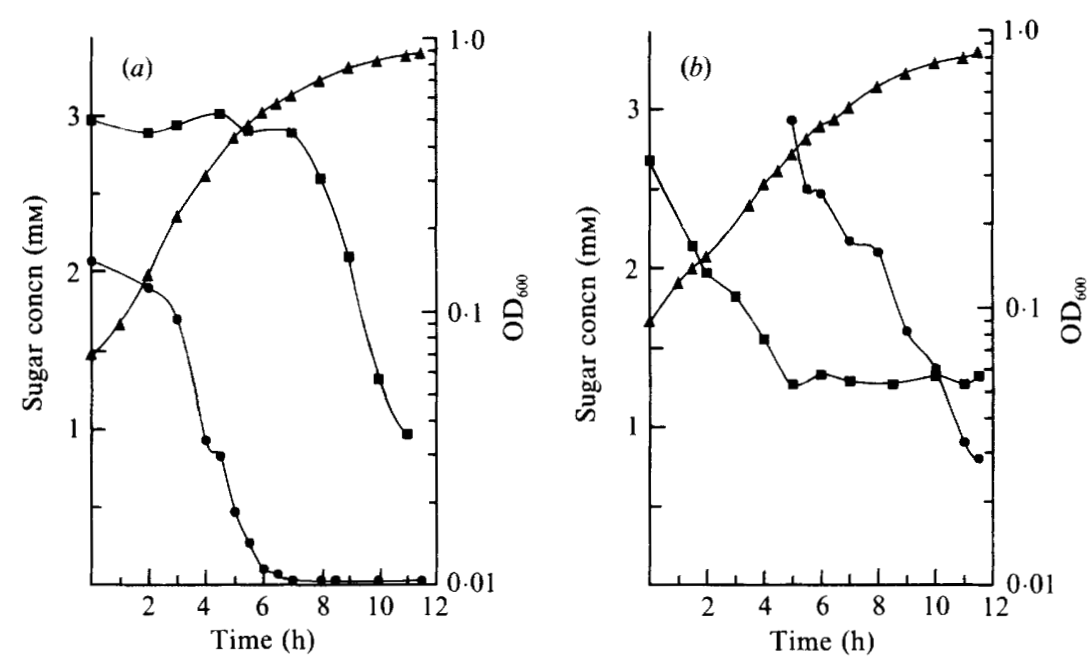

Fig. 1. Utilization of glucose and maltose by $B$. licheniformis. (a) Cells were pregrown on glucose and inoculated into medium containing both glucose and maltose. (b) Cells were pregrown on maltose and inoculated into medium containing maltose as sole carbon source; glucose was then added after $5 \mathrm{~h}$. $\Delta$, $\mathrm{OD}_{600} ; \bullet$, glucose concentration; $\mathbf{\square}$, maltose concentration.

Table 1. Accumulation of glucose and maltose by $B$. licheniformis

\begin{tabular}{|c|c|c|}
\hline \multirow{2}{*}{$\begin{array}{l}\text { Growth } \\
\text { substrate }\end{array}$} & \multicolumn{2}{|c|}{ 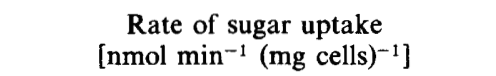 } \\
\hline & Glucose & Maltose \\
\hline Glucose & 40 & Not detected \\
\hline Maltose & 11 & 15 \\
\hline
\end{tabular}

while the maltose transport system appeared to be inducible by its substrate.

To investigate the relationship between glucose and maltose utilization, cultures were grown in the presence of both sugars, and the disappearance of each carbon source was monitored throughout the growth period. When the inoculum was prepared on glucose, this sugar was used preferentially, with maltose being metabolized only when the glucose was depleted from the medium (Fig. $1 a$ ). There was, however, no discernible diauxy in the growth curve. In the converse experiment, cells were first grown on maltose and glucose was added during the growth curve at a stage where enough maltose remained to support growth. Glucose addition did not cause a significant change in the growth rate, but did result in an immediate cessation of maltose uptake, and the added glucose was used instantly and preferentially (Fig. $1 b$ ). This suggests that maltose transport activity is inhibited upon exposure of the cells to glucose, and in fact this has been demonstrated directly in resting cells (data not shown).

\section{Phosphorylation of maltose in cell extracts}

The operation of a phosphotransferase system is most easily revealed by PEP-dependent phosphorylation of the sugar substrate in cell extracts. Therefore, extracts of $B$. licheniformis cells that had been grown on maltose were prepared in potassium phosphate buffer and used in assays of maltose phosphorylation. Surprisingly, maltose was phosphorylated at a significant rate in the presence of inorganic phosphate alone, and this activity was not enhanced by addition of PEP (Fig. 2a). Similarly, ATP did not stimulate the rate of maltose phosphorylation. As we had observed that maltose-grown cells had the capacity to accumulate glucose, the extracts were also assayed for glucose phosphorylation. In contrast to the results obtained with maltose, there was little phosphorylation of glucose in the absence of a high-energy phosphate donor. Both ATP and PEP stimulated the phosphorylation of glucose, demonstrating the existence, respectively, of a glucokinase and a glucose PTS (Fig. 2b).

The possibility that maltose PTS activity was being masked by the high level of sugar phosphate formation in the absence of PEP was investigated by preparing extracts in Tris $/ \mathrm{HCl}$ buffer. In keeping with the lower concentration of phosphate in these extracts, the basal rate of sugar phosphate formation from maltose was greatly diminished (Fig, 3), and was stimulated by addition of potassium phosphate. However, neither PEP nor ATP had any effect on sugar phosphate production from maltose, although both stimulated the phosphorylation of glucose (not shown). These results therefore demonstrate the lack of both a PTS and a kinase for maltose in $B$. licheniformis, but suggest the presence of a maltose phosphorylase which catalyses phosphatedependent maltose phosphorylysis. 


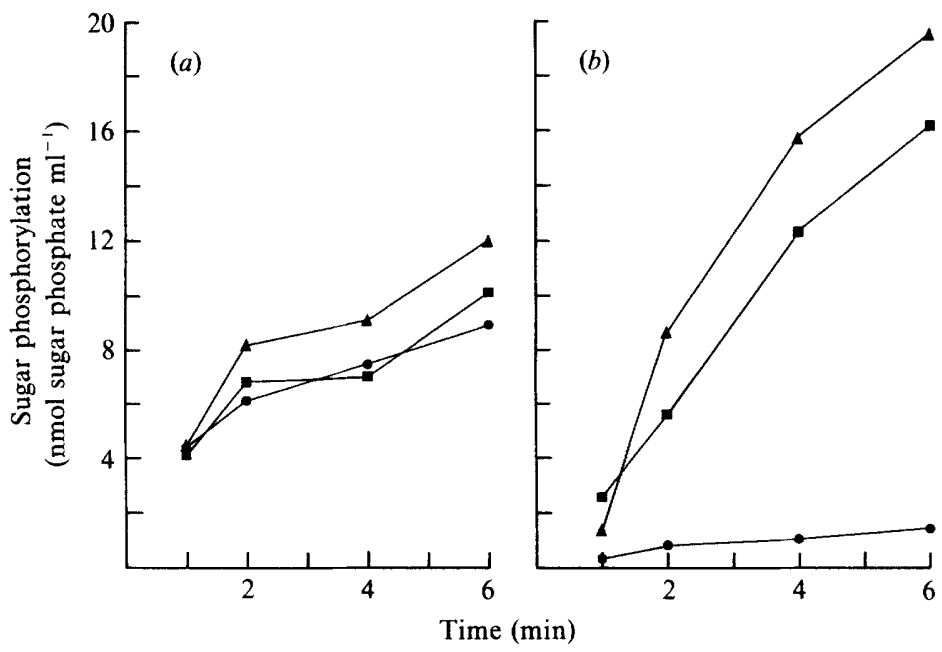

Fig. 2

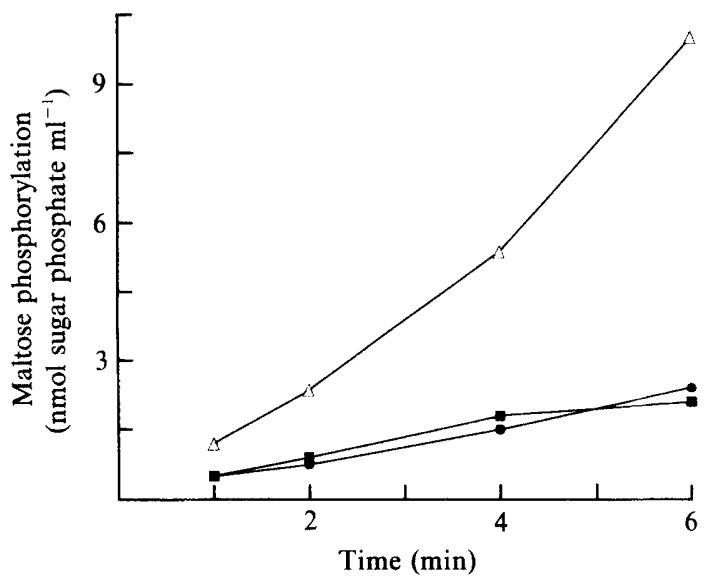

Fig. 3

Fig. 2. Sugar phosphorylation by cell extracts of B. licheniformis. Extracts were prepared in potassium phosphate buffer (100 mM, $\mathrm{pH}$ 6.5) and assayed for phosphorylation of maltose $(a)$ or glucose $(b)$ with the following additions: $\bullet$, no addition; $\boldsymbol{\square}, 1 \mathrm{mM}-\mathrm{PEP} ; \boldsymbol{\Lambda}$, 1 mM-ATP.

Fig. 3. Maltose phosphorylation by cell extracts of $B$. licheniformis. Extracts were prepared in $50 \mathrm{~mm}$ - Tris/ $\mathrm{HCl}$ buffer, $\mathrm{pH} 6.5$, and assayed in the presence of the following: $\bullet$, no addition; $\triangle, 100$ mM-potassium phosphate buffer, pH $6.5 ; \mathbf{m}, 1$ mM-PEP.

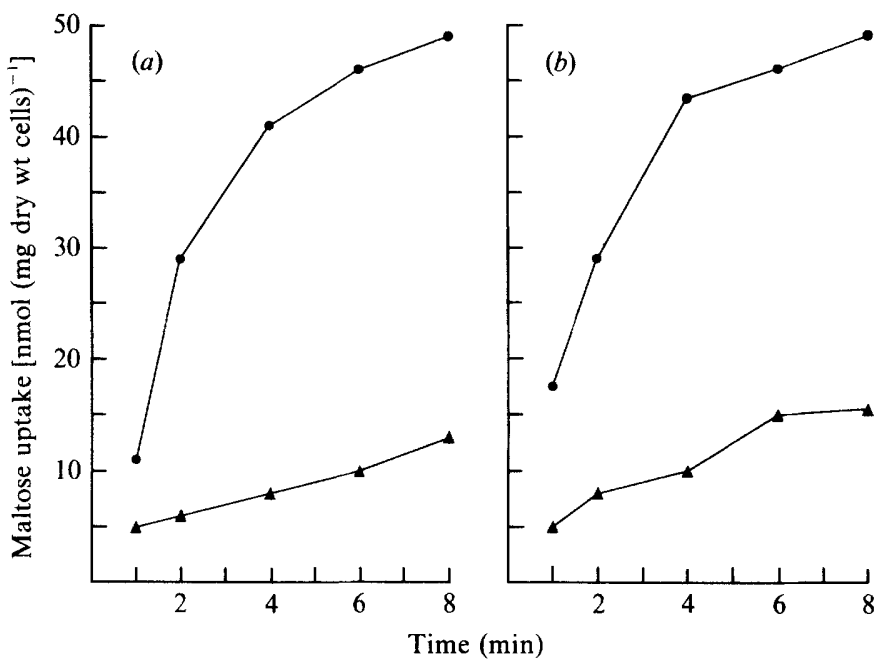

Fig. 4

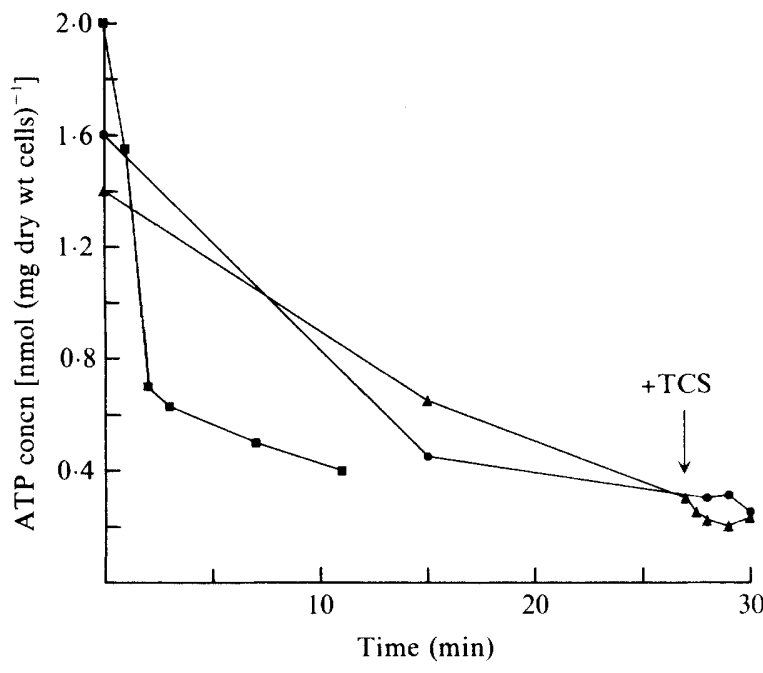

Fig. 5

Fig. 4. Maltose uptake by whole cells of $B$. licheniformis. (a) Cells pre-incubated for 3 min before addition of maltose. (b) Cells preincubated for $30 \mathrm{~min}$ before addition of maltose. - , Control; $\boldsymbol{\Lambda}$, TCS added to a concentration of $5 \mu \mathrm{g} \mathrm{ml}^{-1}$.

Fig. 5. ATP concentration in resting cells of $B$. licheniformis incubated in 100 mM-HEPES buffer, pH 6.6. $\bullet$, No additions; $\boldsymbol{\square}$, TCS $\left(5 \mu \mathrm{g} \mathrm{ml}^{-1}\right)$ added after $3 \mathrm{~min} ; \boldsymbol{\Lambda}$, TCS $\left(5 \mu \mathrm{g} \mathrm{ml}^{-1}\right)$ added after $27 \mathrm{~min}$.

\section{Maltose uptake by whole cells}

The finding of a PTS for glucose, but not maltose, demonstrated that maltose must be transported in B. licheniformis by an alternative mechanism. Accumulation of maltose by resting whole cells was therefore examined, initially by monitoring the effects of energy inhibitors. In the absence of an exogenous energy source, maltose was accumulated at a significant rate, but as shown in Fig. 4 uptake was severely inhibited by the uncoupler TCS. A similar inhibition was found using another uncoupler, CCCP (not shown). These results 


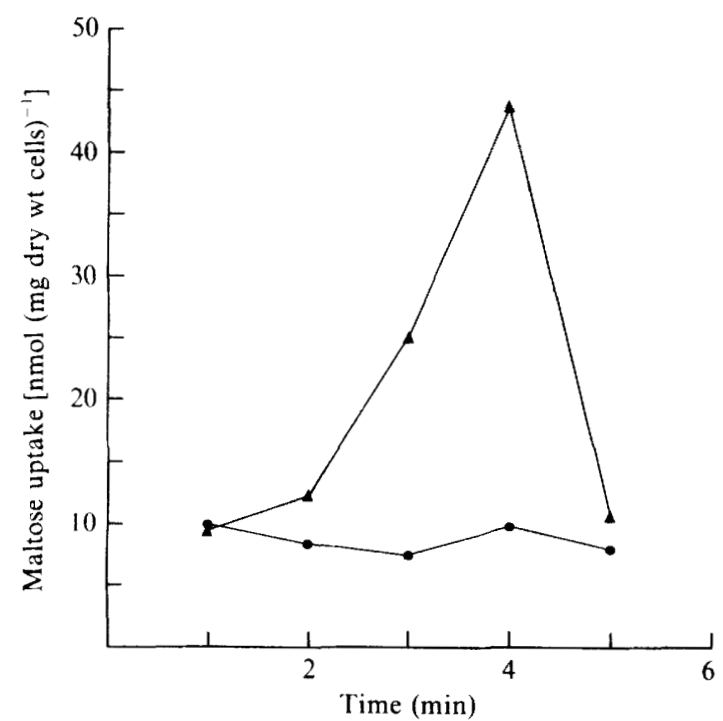

Fig. 6. pH-induced maltose uptake by energy-starved cells of B. licheniformis. Cells were starved by incubation for $2.5 \mathrm{~h}$ in $100 \mathrm{~mm}-$ potassium phosphate buffer, $\mathrm{pH} 8$, at a cell density of $10 \mathrm{mg} \mathrm{ml}^{-1}$. At time zero, cells were diluted tenfold into buffer at $\mathrm{pH} 5.8(\mathrm{~A})$ or $\mathrm{pH} 8$ (•).

indicate that maltose uptake is energy-dependent, and that the transmembrane proton gradient may be involved in energization of maltose uptake. Nevertheless, the possibility also existed that the uncoupler, in addition to dissipating the proton gradient, may have additional secondary effects on cellular energy metabolism. Indeed, TCS was shown to cause a rapid decline in the cellular content of ATP (Fig. 5), and this could clearly cause a significant inhibition of an ATP-dependent maltose transport system. Conditions were therefore established in which the effect of TCS was unambiguous. By incubating the cells in potassium phosphate buffer for $30 \mathrm{~min}$, the ATP pool was depleted to an even lower level, and addition of TCS after this time had only a marginal effect on the ATP concentration (Fig. 5). Cells starved in this way were able to accumulate maltose normally, and TCS had the same effect as in unstarved cells (Fig. 4). Thus, although not completely eliminating the possibility that ATP is involved in energization of maltose uptake, there is no direct correlation between intracellular ATP levels and maltose transport activity. These results strongly suggest that maltose accumulation is dependent on the transmembrane proton gradient.

\section{Maltose uptake driven by an artificial $\mathrm{pH}$ gradient}

By extending the starvation period to $2.5 \mathrm{~h}$, cells were obtained which appeared to be completely devoid of endogenous energy, and were unable to accumulate maltose in standard transport assays. Cells grown on maltose were therefore starved for energy in suspension in potassium phosphate buffer, $\mathrm{pH} 8.0$, at a density of $10 \mathrm{mg} \mathrm{ml}^{-1}$. A sample of the suspension was diluted tenfold into potassium phosphate buffer, $\mathrm{pH} 5 \cdot 8$, thus instantly establishing a $\mathrm{pH}$ gradient, inside alkaline, across the cell membrane. The diluent contained $\left[{ }^{14} \mathrm{C}\right]$ maltose, and accumulation of the sugar was followed. A transient uptake of maltose was observed, although in control experiments in which the diluent was at $\mathrm{pH} 8$ there was no accumulation (Fig. 6). These results show that a transmembrane $\mathrm{pH}$ gradient is sufficient to drive maltose accumulation by $B$. licheniformis, and provide further evidence for a proton symport mechanism.

\section{Discussion}

Maltose and maltodextrins are utilized as a source of carbon and energy by many micro-organisms, but the mechanisms of utilization are poorly understood in most cases. Various mechanisms of maltose transport have been observed. In $E$. coli, the maltose transport system has been well characterized, and shown to consist of three cytoplasmic membrane proteins, a periplasmic binding protein, and a specific outer-membrane porin (Hengge \& Boos, 1983). One of the cytoplasmic membrane proteins, MalK, appears to act as an ATPase, thus allowing the coupling of phosphate-bond energy to maltose accumulation (Higgins et al., 1985). On the other hand, maltose is accumulated by proton symport in the yeast Saccharomyces cerevisiae (Serrano, 1977) and via a phosphotransferase system in Streptococcus bovis (Martin \& Russell, 1987) and S. mutans (Wursch \& Koellreuter, 1985).

Bacilli have been shown to accumulate sugars including glucose, fructose and sucrose by phosphotransferase systems (Kornberg \& Miller, 1972; Gay et al., 1973), but at least in B. subtilis carbohydrates such as gluconate and sorbitol are apparently transported by non-PTS mechanisms (McKillen \& Rountree, 1973; Chalumeau et al., 1978; for reviews see Klier \& Rapoport, 1988; Fisher \& Sonenshein, 1991). B. popilliae has been reported to have a PTS for glucose, although maltose accumulation was by an alternative, undefined mechanism (Taylor \& Costilow, 1977). Our results have shown no evidence for a maltose PTS in B. licheniformis. Maltose transport is, however, clearly energy-dependent, and on the basis of the effects of energy inhibitors and assays of the intracellular ATP pools we have concluded that the most likely mechanism is proton symport. This conclusion was supported by the demonstration that an artificially applied transmembrane $\mathrm{pH}$ gradient could drive the 
uptake of the sugar into the cytoplasm. The possibility that inhibition of maltose accumulation by uncouplers is due to a lowering of the cytoplasmic $\mathrm{pH}$ seemed unlikely since there was a marked reduction in transport activity when cells were resuspended at $\mathrm{pH} 8$ rather than $\mathrm{pH} 6.5$ (data not shown).

If maltose is accumulated by proton symport, it must be hydrolysed in the cytoplasm to yield glucose. In this laboratory, two $\alpha$-glucosidases, designated as pNPGase and maltase, have previously been identified in B. licheniformis (Moore \& Priest, 1987). Both enzymes hydrolyse maltose, although the overall substrate specificities of the enzymes are different. In this study, we have now identified a third maltose-hydrolysing enzyme, which appears to be a maltose phosphorylase. The three activities are induced in parallel during growth on maltose (unpublished results), but the reason for the redundancy of enzymes and the significance of each in maltose metabolism is not clear. It is not possible to exclude a role for the maltose phosphorylase in maltose accumulation, particularly since a small amount of accumulation is consistently seen in the presence of uncouplers (Fig. 4). A redundancy of enzymes involved in maltose and maltodextrin metabolism has in fact been observed frequently in bacteria. E. coli and Streptococcus pneumoniae each contain amylomaltase and maltose phosphorylase (Wiesmeyer \& Cohn, 1960; Lacks, 1968), while $B$. subtilis has been shown to have four $\alpha$-glucosidases, two of which are predominantly active on maltose and two which hydrolyse pNPG but not maltose (G. Chambliss, personal communication). The rumen bacterium $S$. bovis has inducible maltase and maltose phosphorylase enzymes in addition to a maltose PTS (Martin \& Russell, 1987).

Maltose is not metabolized by $B$. licheniformis in the presence of glucose (Fig. 1). Regulation of sugar utilization in bacteria often involves interactions between sugar fluxes into the cell. In enteric bacteria, the exclusion of non-PTS substrates, including maltose, in the presence of glucose involves interaction between a protein component of the glucose PTS (III ${ }^{\text {glc }}$ ) and the non-PTS transport system (Saier, 1989). A similar proposal has been made for regulation of glycerol metabolism in B. subtilis (Reizer et al., 1984), although a recent study of the properties of PTS mutants suggests that the mechanism must be different (Gonzy-Tréboul $e t$ al., 1991). Interestingly, glucose also inhibits maltose uptake in B. subtilis, and ptsI mutants of this bacterium defective in Enzyme I of the PTS are deficient in maltose uptake even though maltose PTS activity has not been demonstrated (unpublished results). It is therefore likely that maltose metabolism is subject to PTS-mediated inhibition. The rapid inhibition of maltose utilization by glucose in growing cells of $B$. licheniformis indicates a direct effect on uptake of maltose, but an understanding of the mechanism of control of maltose metabolism will be dependent on a detailed analysis of the glucose and maltose transport systems and the interactions between them.

This work was supported by the award of a Research Fellowship to M.T. through the EC Biotechnology Action Programme. We are grateful to Professor I. R. Booth for the use of a luminometer for ATP measurements.

\section{References}

BоoтH, I. R. (1988). Bacterial transport: energetics and mechanisms. In Bacterial Energy Transduction, pp. 377-428. Edited by C. Anthony. New York: Academic Press.

Chalumeau, H., Delobbe, A. \& Gay, P. (1978). Biochemical and genetic study of D-glucitol transport and catabolism in Bacillus subtilis. Journal of Bacteriology 134, 920-928.

Dean, D. A., Davidson, A. L. \& Nikaido, H. (1989). Maltose transport in membrane vesicles of Escherichia coli is linked to ATP hydrolysis. Proceedings of the National Academy of Sciences of the United States of America 86, 9134-9138.

Fisher, S. H. \& Sonenshein, A. L. (1991). Control of carbon and nitrogen metabolism in Bacillus. Annual Review of Microbiology 45, 107-135.

GACHELIN (1969). A new assay of the phosphotransferase system in Escherichia coli. Biochemical and Biophysical Research Communications 34, 382-387.

Gay, P., Cordier, P., Marquet, M. \& Delobbe, A. (1973). Carbohydrate metabolism and transport in Bacillus subtilis. A study of ctr mutations. Molecular and General Genetics 121, 355-368.

Gonzy-Tréboul, G., De WaARd, J. H., ZaGorec, M. \& Postma, P. W. (1991). The glucose permease of the phosphotransferase system of Bacillus subtilis: evidence for II $^{\text {glc }}$ and III ${ }^{\text {glc }}$ domains. Molecular Microbiology 5, 1241-1249.

HenGge, R. \& Boos, W. (1983). Maltose and lactose transport in Escherichia coli. Examples of two different types of concentrative transport systems. Biochimica et Biophysica Acta 737, 443-478.

Higgins, C. F., Hiles, I. D., Whalley, K. \& Jamieson, D. J. J. (1985). Nucleotide binding by membrane components of bacterial periplasmic binding protein-dependent transport systems. EMBO Journal 4, 1033-1040.

Kimmich, G. A., RANDLES, J. \& BRAND, J. S. (1975). Assay of picomole amounts of ATP, ADP and AMP using the luciferase enzyme system. Analytical Biochemistry 69, 187-206.

Klier, A. F. \& RAPOPORT, G. (1988). Genetics and regulation of carbohydrate catabolism in Bacillus. Annual Review of Microbiology 42, 65-95.

KoRnberG, H. L. \& MilleR, E. K. (1972). Role of phosphoenolpyruvate-phosphotransferase in glucose utilization by bacilli. Proceedings of the Royal Society of London B182, 171-181.

LACKS, S. (1968). Genetic regulation of maltosaccharide utilization in pneumococcus. Genetics 60, 685-706.

MCKillen, M. N. \& RounTReE, J. H. (1973). D-Gluconate transport in Bacillus subtilis. Biochemical Society Transactions 1, 442-445.

MARTIN, S. A. \& Russell, J. B. (1987). Transport and phosphorylation of disaccharides by the ruminal bacterium Streptococcus bovis. Applied and Environmental Microbiology 53, 2388-2393.

MARTIN, S. A. \& Russell, J. B. (1988). Mechanisms of sugar transport in the rumen bacterium Selenomonas ruminantium. Journal of General Microbiology 134, 819-827.

Meadow, N. M., Fox, D. K. \& Roseman, S. (1990). The bacterial phosphoenolpyruvate:glycose phosphotransferase system. Annual Review of Biochemistry 59, 497-542.

Mitchell, W. J. \& BOOTH, I. R. (1984). Characterization of the Clostridium pasteurianum phosphotransferase system. Journal of General Microbiology 130, 2193-2200. 
MoOre, J. \& Priest, F. G. (1987). Synthesis of two distinct $\alpha$-glucosidase activities in Bacillus licheniformis. Letters in Applied Microbiology 4, 1-3.

Perego, M., Higgins, C. F., Pearce, S. R., Gallacher, M. P. \& HoCH, J. A. (1991). The oligopeptide transport system of Bacillus subtilis plays a role in the initiation of sporulation. Molecular Microbiology 5, 173-185.

Reizer, J., Novotny, M. J., Stuiver, I. \& SAIER, M. H., JR (1984). Regulation of glycerol uptake by the phosphoenolpyruvate-sugar phosphotransferase system in Bacillus subtilis. Journal of Bacteriology 159, 243-250.

Reizer, J., Saier, M. H., Jr, Deutscher, J., Greiner, F., Thompson, J. \& HengstenberG, W. (1988). The phosphoenolpyruvate:sugar phosphotransferase system in Gram-positive bacteria: properties, mechanism, and regulation. CRC Critical Reviews in Microbiology 15, 297-338.

RoOHI, M. S. \& MrtcheLl, W. J. (1987). Regulation of sorbitol metabolism by glucose in Clostridium pasteurianum: a role for inducer exclusion. Journal of General Microbiology 133, 2207-2215.

SAIER, M. H., JR (1989). Protein phosphorylation and allosteric control of inducer exclusion and catabolite repression by the bacterial phosphoenolpyruvate:sugar phosphotransferase system. Microbiological Reviews 53, 109-120.

SERRANO, R. (1977). Energy requirements for maltose transport in yeast. European Journal of Biochemistry 80, 97-102.

Stewart, L. M. D., Bakker, E. P. \& Booth, I. R. (1985). Energy coupling to $\mathrm{K}^{+}$uptake via the Trk system in Escherichia coli: the role of ATP. Journal of General Microbiology 131, 77-85.

TAYLOR, D. C. \& Costilow, R. N. (1977). Uptake of glucose and maltose by Bacillus popilliae. Applied and Environmental Microbiology 34, 102-104.

Thirunavukkarasu, M. \& Priest, F. G. (1980). Regulation of amylase synthesis in Bacillus licheniformis NCIB 6346. FEMS Microbiology Letters 7, 315-318.

WIESMEYER, H. \& COHN, M. (1960). The characterization of the pathway of maltose utilization by Escherichia coli. II. General properties and mechanism of action of amylomaltase. Biochimica et Biophysica Acta 39, 427-439.

WURSCH, P. \& KoEllReUTER, B. (1985). Maltotriitol inhibition of maltose metabolism in Streptococcus mutans via maltose transport, amylomaltase and phospho $\alpha$-glucosidase activities. Caries Research 19, 439-449. 